\title{
Influence of local air pollution on the deposition of peroxyacetyl nitrate to a nutrient-poor natural grassland ecosystem
}

\author{
A. Moravek ${ }^{1, *}$, P. Stella ${ }^{1, * *}$, T. Foken ${ }^{2,3}$, and I. Trebs ${ }^{1, * * *}$ \\ ${ }^{1}$ Max Planck Institute for Chemistry, Biogeochemistry Department, P. O. Box 3060, 55020 Mainz, Germany \\ ${ }^{2}$ Department of Micrometeorology, University of Bayreuth, Universitätsstr. 30, 95447 Bayreuth, Germany \\ ${ }^{3}$ Bayreuth Center of Ecology and Environmental Research (BayCEER), University of Bayreuth, Bayreuth, Germany \\ *now at: Department of Chemistry, University of Toronto, 80 St. George St, M5S 3H6 Toronto, Ontario, Canada \\ ** now at: AgroParisTech, UMR INRA/AgroParisTech SAD-APT, Paris, France \\ **** now at: Luxembourg Institute of Science and Technology, Environmental \\ Research and Innovation (ERIN) Department, 5 avenue des Hauts-Fourneaux, 4362 Esch/Alzette, Luxembourg
}

Correspondence to: A. Moravek (a.moravek@utoronto.ca)

Received: 26 June 2014 - Published in Atmos. Chem. Phys. Discuss.: 8 August 2014

Revised: 4 December 2014 - Accepted: 22 December 2014 - Published: 26 January 2015

\begin{abstract}
Dry deposition of peroxyacetyl nitrate (PAN) is known to have a phytotoxic impact on plants under photochemical smog conditions, but it may also lead to higher productivity and threaten species richness of vulnerable ecosystems in remote regions. However, underlying mechanisms or controlling factors for PAN deposition are not well understood and studies on dry deposition of PAN are limited. In this study, we investigate the impact of PAN deposition on a nutrient-poor natural grassland ecosystem situated at the edge of an urban and industrialized region in Germany. PAN mixing ratios were measured within a 3.5 months summer to early autumn period. In addition, PAN fluxes were determined with the modified Bowen ratio technique for a selected period. The evaluation of both stomatal and nonstomatal deposition pathways was used to model PAN deposition over the entire summer-autumn period. We found that air masses at the site were influenced by two contrasting pollution regimes, which led to median diurnal PAN mixing ratios ranging between 50 and 300 ppt during unpolluted and between 200 and $600 \mathrm{ppt}$ during polluted episodes. The measured PAN fluxes showed a clear diurnal cycle with maximal deposition fluxes of $\sim-0.1 \mathrm{nmol} \mathrm{m}^{-2} \mathrm{~s}^{-1}$ (corresponding to a deposition velocity of $0.3 \mathrm{~cm} \mathrm{~s}^{-1}$ ) during daytime and a significant non-stomatal contribution was found. The ratio of PAN to ozone deposition velocities was found to be $\sim 0.1$, which is much larger than assumed by current deposition models. The modelled PAN flux over the entire pe-
\end{abstract}

riod revealed that PAN deposition over an entire day was $333 \mu \mathrm{g} \mathrm{m}^{-2} \mathrm{~d}^{-1}$ under unpolluted and $518 \mu \mathrm{g} \mathrm{m}^{-2} \mathrm{~d}^{-1}$ under polluted episodes. Additionally, thermochemical decomposition PAN deposition accounted for $32 \%$ under unpolluted episodes and $22 \%$ under polluted episodes of the total atmospheric PAN loss. However, the impact of PAN deposition as a nitrogen source to the nutrient-poor grassland was estimated to be only minor, under both unpolluted and polluted episodes.

\section{Introduction}

Originating from both anthropogenic and natural sources, peroxyacetyl nitrate $\left(\mathrm{CH}_{3} \mathrm{C}(\mathrm{O}) \mathrm{O}_{2} \mathrm{NO}_{2}\right.$, PAN) is primarily known as an atmospheric pollutant. Both the peroxyacetyl radical $\left(\mathrm{CH}_{3} \mathrm{C}(\mathrm{O}) \mathrm{O}_{2}, \mathrm{PA}\right)$ and nitrogen dioxide $\left(\mathrm{NO}_{2}\right)$, which form PAN via

$\mathrm{CH}_{3} \mathrm{C}(\mathrm{O}) \mathrm{O}_{2}+\mathrm{NO}_{2}+M \stackrel{k 1}{\rightleftarrows} \mathrm{CH}_{3} \mathrm{C}(\mathrm{O}) \mathrm{O}_{2} \mathrm{NO}_{2}+M$,

have anthropogenic sources. Due to its thermal instability via the back-reaction of R1 and subsequent reaction of PA with nitric oxide (NO),

$\mathrm{CH}_{3} \mathrm{C}(\mathrm{O}) \mathrm{O}_{2}+\mathrm{NO} \stackrel{k 2}{\longrightarrow} \mathrm{CH}_{3} \mathrm{C}(\mathrm{O}) \mathrm{O}+\mathrm{NO}_{2}$,

long-range transport of PAN in cold layers of the upper troposphere may constitute a significant source of reactive ni- 
trogen $\left(\mathrm{N}_{\mathrm{r}}=\right.$ sum of oxidized and reduced nitrogen in remote regions). Consequently, it affects e.g. the production of ozone $\left(\mathrm{O}_{3}\right)$ and links the atmospheric and biospheric nitrogen cycle through dry deposition (Singh, 1987). Besides, locally produced PAN may also impact on ecosystems downwind of pollution sources. While for high PAN mixing ratios (>15 ppb), prevailing under strong photochemical smog conditions, PAN is known to be phytotoxic and may harm plant tissues significantly (Temple and Taylor, 1983), the impact of PAN deposition under less extreme conditions and for lower PAN mixing ratios is not yet clear. As a nitrogen source, PAN deposition may also lead to higher productivity and may threaten species richness especially in vulnerable ecosystems (Stevens et al., 2010).

Previous studies on the surface-atmosphere exchange of PAN showed that PAN is deposited to vegetation. On the one hand, chamber experiments on PAN uptake on both leaf and plant level (Okano et al., 1990; Sparks et al., 2003; Teklemariam and Sparks, 2004) found a direct relationship between PAN uptake and stomatal conductance. They suggest that stomatal uptake is the major pathway of PAN into leaves. On the other hand, previous studies have also shown the existence of non-stomatal deposition of PAN, mainly associated with the uptake by the leaf cuticles (Teklemariam and Sparks, 2004; Turnipseed et al., 2006; Wolfe et al., 2009). While Turnipseed et al. (2006) found almost $50 \%$ of the daytime deposition to be non-stomatal for a pine forest and suggest it to be the primary deposition pathway in the upper canopy, Wolfe et al. (2009) attribute between 21 and $35 \%$ (for warm and cold periods, respectively) of the deposition flux to nonstomatal pathways for a pine forest site. However, conclusive studies on PAN fluxes are currently very limited and the obtained results differ considerably. The underlying mechanisms or controlling factors for PAN deposition, like the role of wet surfaces, as well as the relation of PAN to $\mathrm{O}_{3}$ deposition fluxes, are not well understood.

Grassland ecosystems are the third largest land use type in Europe and constitute $41 \%$ of global terrestrial surfaces (EUROSTAT, 2011; Suttie et al., 2005). Moreover, nutrient-poor habitats, where additional nitrogen input via deposition may play a significant role, are often dominated by grass species rather than trees. In this case study, we investigate the influence of polluted and non-polluted air masses on the dry deposition of PAN at a nutrient-poor natural grassland ecosystem in Central Europe. PAN mixing ratios were measured and analysed over a 3-month period under two contrasting pollution regimes. For a selected period, we also derived PAN fluxes with the flux-gradient approach, employing a newly developed flux measurements system for PAN (Moravek et al., 2014). In addition, fluxes of $\mathrm{O}_{3}$, which has similarities to PAN in terms of its formation and deposition and thus is important for model applications, were determined by eddy covariance. Based on our approaches, we estimate the contribution of stomatal and non-stomatal deposition pathways for PAN and compare these results to those obtained for $\mathrm{O}_{3}$.

\section{Methods}

\subsection{Site description}

The study was conducted at a nutrient-poor natural grassland ecosystem on the estate of the Mainz Finthen Airport in Rhineland-Palatinate, Germany $\left(49.9685^{\circ} \mathrm{N}, 8.1481^{\circ} \mathrm{E}\right)$. The natural grassland area of the measurement site extends over an area of $0.7 \times 2.0 \mathrm{~km}$ (in mainly east-west orientation), providing good fetch condition for micrometeorological flux measurements. The ecosystem is primarily unmanaged and the vegetation is characterized by the false oatgrass plant community (Arrhenatherion elatioris) on dry and sandy soil with a considerable amount of senescent or diedoff grass. Small bushes were occasionally removed and parts of the grassland were grazed by sheep once a year. The soil nitrate content was very low $\left(\sim 0.7 \mathrm{mg} \mathrm{kg}^{-1}\right.$ in the upper $5 \mathrm{~cm}$ ) and, hence, ammonium was most likely the largest source of plant-available nitrogen from soil $\left(\sim 20 \mathrm{mg} \mathrm{kg}^{-1}\right.$ in the upper $5 \mathrm{~cm}$ ) (Oswald et al., 2013). The mean canopy height during the field campaign was $0.6 \mathrm{~m}$ and the bulk leaf area index (LAI) for both green and brown grass was on average 4.8. A roughness length $\left(z_{0}\right)$ of $0.1 \mathrm{~m}$ and a zero plane displacement $(d)$ of $0.45 \mathrm{~m}$ were estimated using the approach of De Bruin and Moore (1985) for canopies with increased roughness. The site is topographically located on a plateau $150 \mathrm{~m}$ above the Rhine valley and located about $9 \mathrm{~km}$ southwest of the city centre of Mainz (Fig. 1). The plateau is part of region Rhenish Hesse, which extends to the south and southwest and is characterized by agricultural land use (mainly vineyards, orchards and crops) and smaller villages. In contrast, the industrialized and densely populated RhineMain area extends to northerly and easterly directions. Two motorways pass close to the north and east of the site at a distance of 2 and $4 \mathrm{~km}$, respectively.

\subsection{Measurements of PAN mixing ratios and fluxes}

PAN mixing ratios on the site were measured for a 3.5-month period in summer and early autumn 2011 (29 June to 21 October 2011) using a gas chromatograph with electron capture detection (GC-ECD, see Moravek et al. (2014) for detailed description). The GC-ECD was placed in an air-conditioned container and regularly calibrated with air from a photolytic calibration source.

In addition, during the period from 19 August to 4 September we performed gradient measurements at 0.8 and $4.0 \mathrm{~m}$ a.g.l. to determine biosphere-atmosphere exchanges fluxes via the modified Bowen ratio (MBR) technique (Businger, 1986). The PAN flux ( $\left.F_{\mathrm{MBR}_{\mathrm{PAN}}}\right)$ was estimated by the ratio of the $\mathrm{PAN}$ and $\mathrm{O}_{3}$ mixing ratio difference between the upper and lower measurement height, $\Delta c_{\mathrm{PAN}}$ and $\Delta c_{\mathrm{O}_{3}}$, multiplied by the eddy covariance flux of $\mathrm{O}_{3}\left(F_{\mathrm{EC}_{3}}\right)$ :

$F_{\mathrm{MBR}_{\mathrm{PAN}}}=F_{\mathrm{EC}_{\mathrm{O}_{3}}} \cdot \frac{\Delta c_{\mathrm{PAN}}}{\Delta c_{\mathrm{O}_{3}}} \approx F_{\mathrm{EC}_{\mathrm{O}_{3}}} \cdot \frac{\Delta \chi_{\mathrm{PAN}}}{\Delta \chi_{\mathrm{O}_{3}}}$. 
We used $\mathrm{O}_{3}$ as a proxy scalar due to its similarity to PAN in the sink and source distribution. On the one hand, the production of both PAN and $\mathrm{O}_{3}$ is linked to photochemical processes and, on the other hand, both compounds are known to deposit to vegetation. Instead of using concentration differences in Eq. (1), we used the mixing ratio differences of PAN $\left(\Delta \chi_{\mathrm{PAN}}\right)$ and $\mathrm{O}_{3}\left(\Delta \chi_{\mathrm{O}_{3}}\right)$ since the differences in the molar air density between the two heights were negligible. The correction of PAN fluxes for the loss by thermochemical decomposition of PAN is presented in Sect. 2.5. The storage term (see e.g. Rummel et al., 2007) of PAN was estimated using a logarithmically interpolated vertical profile of PAN and was found to be negligible. Further details on the flux measurements, including necessary modifications of the GCECD and the inlet system, and an extensive error analysis are given in Moravek et al. (2014). Flux values with random errors larger than $100 \%$ were regarded as below the flux detection limit. Furthermore, under conditions with low friction velocities $\left(u_{*}<0.07 \mathrm{~m} \mathrm{~s}^{-1}\right)$ the application of the MBR methods is prone to larger errors (Liu and Foken, 2001).

\subsection{Additional measurements}

For the determination of $\mathrm{O}_{3}$ eddy covariance fluxes, required for the application of the MBR method, a closed-path fastresponse $\mathrm{O}_{3}$ detector (Enviscope $\mathrm{GmbH}$, Germany) was employed together with a sonic anemometer (CSAT3, Campbell Scientific Inc., USA) at $z_{\text {ref }}=3 \mathrm{~m}$ a.g.l. (see Moravek et al. (2014) for details on eddy covariance setup and $\mathrm{O}_{3}$ calibration). In addition, $\mathrm{CO}_{2}$ and latent heat fluxes were determined with an open-path $\mathrm{CO}_{2} / \mathrm{H}_{2} \mathrm{O}$ analyser (LI-7500A, LICOR, USA). All turbulent fluxes were calculated using the eddy covariance software TK3.1 (Mauder and Foken, 2011), applying state-of-the-art corrections methods as listed in Foken et al. (2012). Additionally, the $\mathrm{O}_{3}$ flux was corrected for high-frequency loss of the $2.5 \mathrm{~m}$ long inlet tube (Moravek et al., 2013), for the storage effect and for chemical production from $\mathrm{NO}_{2}$ photolysis and loss by reaction with $\mathrm{NO}$ (Rummel et al., 2007). The nighttime removal pathway of $\mathrm{O}_{3}$ via the reaction with $\mathrm{NO}_{2}$ forming $\mathrm{NO}_{3}$ (see e.g. Brown and Stutz, 2012) was found to be insignificant as the reaction rate is about one order of magnitude lower than of the reaction of $\mathrm{O}_{3}$ with NO. The quality scheme of Foken and Wichura (1996) was used to exclude periods with significant non-stationarity or poor developed turbulence. Data for which the footprint area of the flux measurement (calculated with a Lagrangian forward stochastic model from Rannik et al., 2000) included less than $80 \%$ of the natural grassland area were omitted.

The mixing ratio difference of $\mathrm{O}_{3}$ between 4.0 and $0.8 \mathrm{~m}$ a.g.l. was determined using a differential UV absorption $\mathrm{O}_{3}$ analyser (49i, Thermo Environmental, USA, modified according to Cazorla and Brune (2010); see Moravek et al. (2014) for details on operation). Absolute $\mathrm{O}_{3}$ mixing ratios at both heights were derived from a vertical profile system, which also measured $\mathrm{NO}$ and $\mathrm{NO}_{2}$ mixing ratios
$\left(\mathrm{O}_{3}\right.$ analyser: 49i, Thermo Environmental, USA; $\mathrm{NO} / \mathrm{NO}_{2}$ analyser: CLD 780 TR, Eco-Physics, Switzerland). A vertical profile of temperature, humidity and wind speed was retrieved at $0.2,0.8,1.5,2.5$ and $4.0 \mathrm{~m}$ a.g.l.

Meteorological parameters used in this study are global radiation (CNR1, Kipp \& Zonen, Netherlands), $\mathrm{NO}_{2}$ photolysis frequency $\left(\mathrm{N}_{2} \mathrm{O}_{2}\right)$ (Meteorologie Consult $\mathrm{GmbH}$, Germany), rainfall (AGR100, Environmental Measurements) and surface wetness (Campbell Scientific Inc., USA). All additional measurements were performed during the entire experiment period from 29 June to 21 October 2011.

\subsection{Flux partitioning}

As PAN and $\mathrm{O}_{3}$ are depositing, the $\mathrm{PAN}$ and $\mathrm{O}_{3}$ flux can be partitioned into deposition to leaf stomata $\left(F_{\mathrm{s}}\right)$ and to nonstomatal surfaces $\left(F_{\mathrm{ns}}\right)$ :

$F=F_{\mathrm{s}}+F_{\mathrm{ns}}$

Following the big leaf multiple resistance approach (Hicks et al., 1987; Wesely and Hicks, 2000) the overall canopy conductance $-g_{\mathrm{c}}$, a combination of the stomatal $\left(g_{\mathrm{s}}\right)$, the mesophyll $\left(g_{\mathrm{m}}\right)$ and the non-stomatal $\left(g_{\mathrm{ns}}\right)$ conductance - was obtained for both PAN and $\mathrm{O}_{3}$ from the measured deposition velocity $\left(v_{\mathrm{D}}\right.$, i.e. the flux normalized by the concentration at $\left.z_{\text {ref }}\right)$ and the estimated aerodynamic $\left(R_{\mathrm{a}}\right)$ and quasilaminar boundary layer $\left(R_{\mathrm{b}}\right)$ resistances (see Garland, 1977, and Hicks et al., 1987, respectively):

$g_{\mathrm{c}}=\frac{1}{\frac{1}{g_{\mathrm{s}}}+\frac{1}{g_{\mathrm{m}}}}+g_{\mathrm{ns}}=\left(\frac{1}{v_{\mathrm{D}}}-R_{\mathrm{a}}-R_{\mathrm{b}}\right)^{-1}$.

In the case that processes in the leaf mesophyll (or surrounding components) do not limit the trace gas exchange (i.e. $1 / g_{\mathrm{m}} \sim 0$ ), as in the case of water vapour or $\mathrm{O}_{3}, g_{\mathrm{c}}$ simply equals the sum of $g_{\mathrm{s}}$ and $g_{\mathrm{ns}}$. For the calculation of the PAN stomatal uptake, no limitation of PAN uptake by the mesophyll was assumed as a first approach (see Sect. 3.3.2 for discussion on $g_{\mathrm{m}}$ ). Following e.g. Lamaud et al. (2009) and Stella et al. (2011), $g_{\mathrm{SPAN}}$ and $g_{\mathrm{SO}_{3}}$ were derived from the stomatal conductance for water vapour via the Penman-Monteith equation $\left(g_{\mathrm{SPM}}\right)$ corrected for the ratio of their molecular diffusivities to the molecular diffusivity of water vapour. Due to its longer molecular structure, the diffusivity of PAN is lower $\left(D_{\text {PAN }} \sim 0.87 \times 10^{-5} \mathrm{~m}^{2} \mathrm{~s}^{-1}\right.$ ) than for $\mathrm{O}_{3}\left(D_{\mathrm{O}_{3}} \sim 1.40 \times 10^{-5} \mathrm{~m}^{2} \mathrm{~s}^{-1}\right)$, which results in $g_{\mathrm{SPAN}_{\mathrm{P}}} / g_{\mathrm{S}_{\mathrm{O}_{3}}}=0.62$ (derived from Hicks et al., 1987). Since the measured $\mathrm{H}_{2} \mathrm{O}$ flux, on which the Penman-Monteith equation is based, originated not only from transpiration through the plant stomata but also from water evaporation from other sources such as soil pores or liquid water on different surfaces, we only used dry conditions with relative humidities $(\mathrm{RH})<60 \%$ to compute $g_{\mathrm{SPM}}$. Under these conditions liquid water on surfaces is assumed to be fully evaporated. Soil evaporation was excluded from $g_{\mathrm{SPM}}$ according to 
Stella et al. (2011). The final $g_{\mathrm{S}_{\mathrm{PM}}}$ values for the entire relative humidity range were determined as a function of the corrected $g_{\mathrm{SPM}}$ values against the gross primary production (GPP).

Finally, $g_{\text {ns }}$, representing all non-stomatal deposition pathways, e.g. to leaf cuticles, soil or water surfaces, was derived by the difference between $g_{\mathrm{c}}$ and $g_{\mathrm{s}}$ (Eq. 3).

The findings on $g_{\text {nSPAN }}$ from the partitioning of $F_{\mathrm{MBR}_{\mathrm{PAN}}}$ were used to model PAN deposition fluxes for the entire period from 29 June to 21 October. Applying the resistive scheme given in Eq. (3), the modelled PAN flux $\left(F_{\text {modelpAN }}\right)$ was derived as

$$
\begin{aligned}
F_{\text {model }_{\mathrm{PAN}}} & =-\left(R_{\mathrm{a}}+R_{\mathrm{b}_{\mathrm{PAN}}}+\frac{1}{g_{\mathrm{SPAN}}+g_{\mathrm{n} \mathrm{PAN}}}\right)^{-1} \\
& \cdot \rho_{\mathrm{m}} \cdot \chi_{\mathrm{PAN}}
\end{aligned}
$$

where $R_{\mathrm{a}}, R_{\mathrm{b}_{\mathrm{PAN}}}$ and $g_{\mathrm{SPAN}}$ were determined as described above over the entire period. Here, $\rho_{\mathrm{m}}$ and $\chi_{\mathrm{PAN}}$ represent the molar air density and the PAN mixing ratio, respectively, at the height of the eddy covariance measurements $\left(z_{\text {ref }}\right)$

\subsection{Determination of PAN loss by thermochemical decomposition}

In addition to the dry deposition process, other sink terms impact the measured surface PAN mixing ratios. While PAN photolysis and reaction with the hydroxyl radical $(\mathrm{OH})$ are expected to be very low at altitudes below $7 \mathrm{~km}$ (Talukdar et al., 1995), thermochemical decomposition of PAN (backreaction of R1) has to be considered. Thermochemical decomposition of PAN increases exponentially with temperature and is more efficient at high $\mathrm{NO} / \mathrm{NO}_{2}$ ratios as PA reacts faster with $\mathrm{NO}$ than with $\mathrm{NO}_{2}$ to reform PAN. Hence, the timescale of PAN towards thermochemical decomposition $\left(\tau_{\text {chem }}\right)$ is given (Orlando et al., 1992; Shepson et al., 1992) as

$\tau_{\text {chem }}(\mathrm{PAN})=\frac{1}{k_{1 r}}\left(1+\frac{k_{1 f}\left[\mathrm{NO}_{2}\right]}{k_{2}[\mathrm{NO}]}\right)$.

In addition, loss of PA due to uptake by fog droplets can have an influence on the thermochemical decomposition of PAN (see Roberts et al., 1996; Villalta et al., 1996). However, since at night, when fog conditions may have occurred, the thermochemical decomposition of PAN was limited by the low temperatures, this effect was neglected for this study.

To evaluate whether PAN loss by thermochemical decomposition significantly impacted the MBR fluxes (Sect. 2.2), the chemical flux divergence between $z_{\text {ref }}$ and $z_{0}$ due to thermochemical decomposition of PAN $\left(F_{\text {chem }_{\text {surf }}}\right)$ was determined according to Doskey et al. (2004) by numeric integration of the thermochemical PAN loss as

$F_{\text {chem }_{\text {surf }}}=\int_{z_{0}}^{z_{\text {ref }}} \frac{\rho_{\mathrm{m}}(z) \cdot \chi_{\text {PAN }}(z)}{\tau_{\text {chem }}(z)} \mathrm{d} z$.
The height-dependent functions of $\chi_{\mathrm{PAN}}(z)$ and $\tau_{\text {chem }}(z)$ were approximated by logarithmic interpolation between the available measurement heights of the required parameters and $\rho_{\mathrm{m}}(z)$ was assumed to be constant with height (see Sect. 2.2).

The thermochemical PAN loss over the entire atmospheric boundary layer, represented as a flux $\left(F_{\text {chem }}\right)$, was obtained by integrating Eq. (6) from zero level to the height of the boundary layer $\left(h_{\mathrm{BL}}\right)$ :

$F_{\text {chem }_{\text {BL }}}=\int_{0}^{h_{\mathrm{BL}}} \frac{\rho_{\mathrm{m}}(z) \cdot \chi_{\mathrm{PAN}}(z)}{\tau_{\text {chem }}(z)} \mathrm{d} z$.

Assuming a well-mixed boundary layer, the measured PAN concentration and $\mathrm{NO} / \mathrm{NO}_{2}$ ratio were taken as an average value for the whole boundary layer. As $\tau_{\text {chem }}$ is very sensitive to temperature, we assumed a dry adiabatic lapse rate of temperature with height. The height of the nocturnal boundary layer was estimated from the nocturnal decline of $\mathrm{O}_{3}$ and the corresponding measured $v_{\mathrm{D}_{\mathrm{O}_{3}}}$ from the relation given by Shepson et al. (1992) (see also Sect. 3.3.3) as

$h_{\mathrm{BL} \_ \text {night }}=2 \cdot v_{\mathrm{D}_{\mathrm{O}_{3}}} \cdot \ln \frac{\chi_{\mathrm{O}_{3}}\left(t_{0}\right)}{\chi_{\mathrm{O}_{3}}\left(t_{1}\right)}$,

where $\chi_{\mathrm{O}_{3}}\left(t_{0}\right)$ and $\chi_{\mathrm{O}_{3}}\left(t_{1}\right)$ are the $\mathrm{O}_{3}$ mixing ratios at the start and end of the considered time interval, respectively. Since $h_{\text {BL_night }}$ was determined from a boundary layer budget approach, it might not agree well with the real boundary layer height, as the nocturnal boundary layer might be significantly stratified. Instead, $h_{\text {BL_night }}$ represents the theoretical depth of a mixed boundary layer, which was required in Eq. (7) to assume constant trace gas mixing ratios with height. The development of the diurnal boundary layer $\left(h_{\text {BL_day }}\right)$ after dawn was modelled using the measured sensible heat surface flux and a simple encroachment approach implemented in the mixed layer model MXLCH (Vilà-Guerau de Arellano et al., 2011).

\section{Results and discussions}

\subsection{Meteorological conditions: classification of low and high $\mathrm{NO}_{\mathrm{x}}$ episodes}

The field experiment was dominated by wind directions from the southwest. These air masses were associated with relatively low levels of $\mathrm{NO}_{\mathrm{x}}\left(=\mathrm{NO}+\mathrm{NO}_{2}\right)$ (ranging mainly between 1 and $10 \mathrm{ppb}$ ). Air masses from northeasterly directions were much less frequent, but were often enriched with $\mathrm{NO}_{\mathrm{x}}$ with values ranging mainly between 10 and $30 \mathrm{ppb}$ (Fig. 1). This enrichment was mainly caused by advection from $\mathrm{NO}_{\mathrm{x}}$ sources originated from the city of Mainz, nearby motorways and other sources in the densely populated and industrialized Rhine-Main region. In contrast, the southwest 


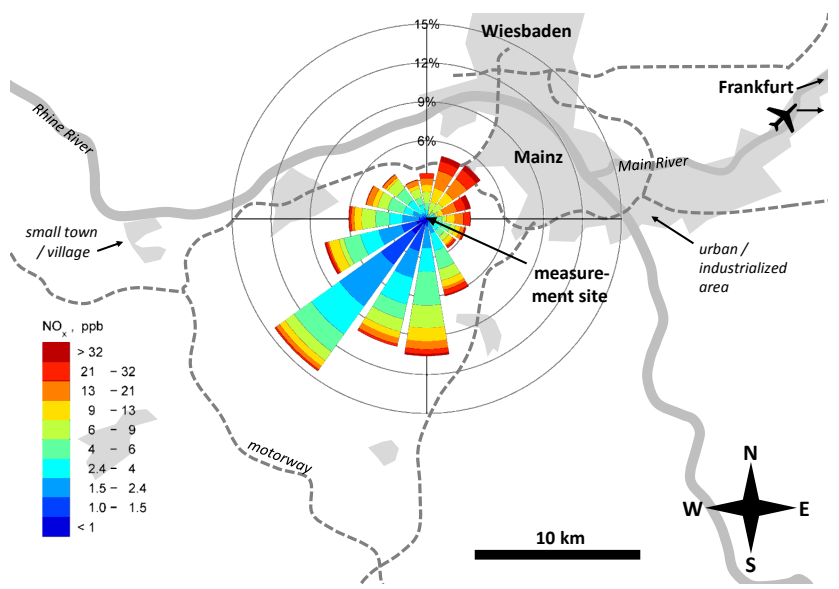

Figure 1. Location of the Mainz Finthen grassland site located at the edge of the industrialized Rhine-Main area in Germany. The wind rose, centred at the measurement site, indicates unpolluted (low $\mathrm{NO}_{\mathrm{x}}$ ) air masses from the south west sector and more polluted (high $\mathrm{NO}_{\mathrm{X}}$ ) air masses from north easterly directions.

sector is dominated by farming without major industrial activity, thus representing an area with much less air pollution. Consequently, the occurrence of low and high $\mathrm{NO}_{\mathrm{x}}$ situations during the field experiment was directly coupled to the wind direction and could be attributed to two contrasting synoptic conditions:

1. Episodes under deep pressure influence and southwesterly wind directions yielded low $\mathrm{NO}_{\mathrm{x}}$ conditions. They were characterized by higher wind speeds, frequent cloud coverage, a mainly neutrally stratified boundary layer and typically lasted from 2 to 5 days.

2. Sunny, convectively driven episodes with low wind speeds and, therefore, also varying wind directions resulted in high $\mathrm{NO}_{\mathrm{x}}$ conditions, in cases when the wind direction was not from the southwest sector. In contrast to the low $\mathrm{NO}_{\mathrm{x}}$ conditions, these periods occurred sometimes as very isolated events and were associated with an unstable boundary layer during daytime and a stable stratification during nighttime.

For the further evaluation, entire days were selected and classified according to wind speed and wind direction. In total 20 days were classified as low $\mathrm{NO}_{\mathrm{x}}$ and 27 days as high $\mathrm{NO}_{\mathrm{x}}$ conditions. The diurnal averages of the meteorological conditions and micrometeorological characteristics during these days are displayed in Fig. 2a-f and mixing ratios of $\mathrm{O}_{3}, \mathrm{NO}$ and $\mathrm{NO}_{2}$ are shown in Fig. $2 \mathrm{~g}-\mathrm{i}$. For both low and high $\mathrm{NO}_{\mathrm{x}}$ conditions, photolysis of $\mathrm{NO}_{2}$ contributed to the steady increase of NO mixing ratios after sunrise, which peaked between 08:00 and 10:00 CET and then declined with the growth of the daytime boundary layer. During high $\mathrm{NO}_{\mathrm{x}}$ conditions both advection of freshly emitted $\mathrm{NO}$ from nearby sources and generally higher $\mathrm{NO}_{2}$ levels lead to high NO mixing ratios exceeding sometimes $10 \mathrm{ppb}$. Biogenic NO emission from the grassland ecosystem, determined with the dynamic chamber method, were found to be insignificant (Plake et al., 2015). $\mathrm{NO}_{2}$ mixing ratios showed a high variability during high $\mathrm{NO}_{\mathrm{x}}$ conditions, also indicating local sources. The daytime $\mathrm{NO}_{2}$ decline was caused by both dilution due to the growing boundary layer and photolysis. It was anti-correlated with the increase of $\mathrm{O}_{3}$ mixing ratios. The development of a shallow nocturnal inversion layer during high $\mathrm{NO}_{\mathrm{x}}$ conditions caused increased $\mathrm{O}_{3}$ removal rates. As a result, nighttime $\mathrm{O}_{3}$ mixing ratios were lower than during low $\mathrm{NO}_{\mathrm{x}}$ conditions. During daytime, both the higher insolation and the presence of pollutants under high $\mathrm{NO}_{\mathrm{x}}$ conditions resulted in higher $\mathrm{O}_{3}$ mixing ratios during the afternoon.

\subsection{Characterization of PAN under low and high $\mathrm{NO}_{\mathrm{x}}$ conditions}

The diurnal cycle of PAN mixing ratios was closely linked to the diurnal cycle of $\mathrm{O}_{3}$. As for $\mathrm{O}_{3}$, PAN mixing ratios increased after dawn to the maximum in the afternoon, with median values of $300 \mathrm{ppt}$ under low and of $600 \mathrm{ppt}$ under high $\mathrm{NO}_{\mathrm{x}}$ conditions, respectively (Fig. 2j). The maximum was followed by a steady decrease over night to median values just before dawn of about $50 \mathrm{ppt}$ under low $\mathrm{NO}_{\mathrm{x}}$ and $200 \mathrm{ppt}$ under high $\mathrm{NO}_{\mathrm{x}}$ conditions.

The major reason for the much higher PAN levels during high $\mathrm{NO}_{\mathrm{x}}$ conditions are the elevated $\mathrm{NO}_{2}$ mixing ratios, which occurred especially during nighttime and declined with the onset of photolysis after dawn and the clearing of the nocturnal boundary layer. Comparing the diurnal evolution of $\mathrm{PAN}$ and $\mathrm{O}_{3}$ mixing ratios, we find a higher $\mathrm{PAN} / \mathrm{O}_{3}$ ratio under high $\mathrm{NO}_{\mathrm{x}}$ conditions at all times throughout the diurnal cycle. During peak PAN and $\mathrm{O}_{3}$ mixing ratios in the afternoon, the $\mathrm{PAN} / \mathrm{O}_{3}$ ratio was 0.003 and 0.006 during low and high $\mathrm{NO}_{\mathrm{x}}$ conditions, respectively. Since photolytic production of $\mathrm{O}_{3}$ from $\mathrm{NO}_{2}$ was similar for both conditions, a large $\mathrm{PAN} / \mathrm{O}_{3}$ ratio implies a higher abundance of $\mathrm{PA}$ as a precursor of PAN (Zhang et al., 2009). Although no direct measurements of PA were available, the very low abundance of volatile organic compounds measured at the site (e.g. isoprene $<0.7 \mathrm{ppb}$, monoterpene $<0.3 \mathrm{ppb}$; J. Kesselmeier, personal communication, 2013) suggests that these higher levels of PA during high $\mathrm{NO}_{\mathrm{x}}$ conditions primarily originated from anthropogenic non-methane hydrocarbons (NMHCs). Hence, PAN mixing ratios at the site were mainly influenced by advection from nearby pollution sources from northeasterly directions.

The timescale for thermochemical decomposition of PAN, $\tau_{\text {chem }}$, ranged for both low and high $\mathrm{NO}_{\mathrm{x}}$ conditions mainly between 4 and 20 days at night (Fig. 2k). During daytime, $\tau_{\text {PAN }}$ ranged between $2 \mathrm{~h}$ and nearly 1 day (median $\sim 5 \mathrm{~h}$ ) for low $\mathrm{NO}_{\mathrm{x}}$ conditions, but were significantly lower during high $\mathrm{NO}_{\mathrm{x}}$ conditions (ranging between $30 \mathrm{~min}$ and $5 \mathrm{~h}$; me- 

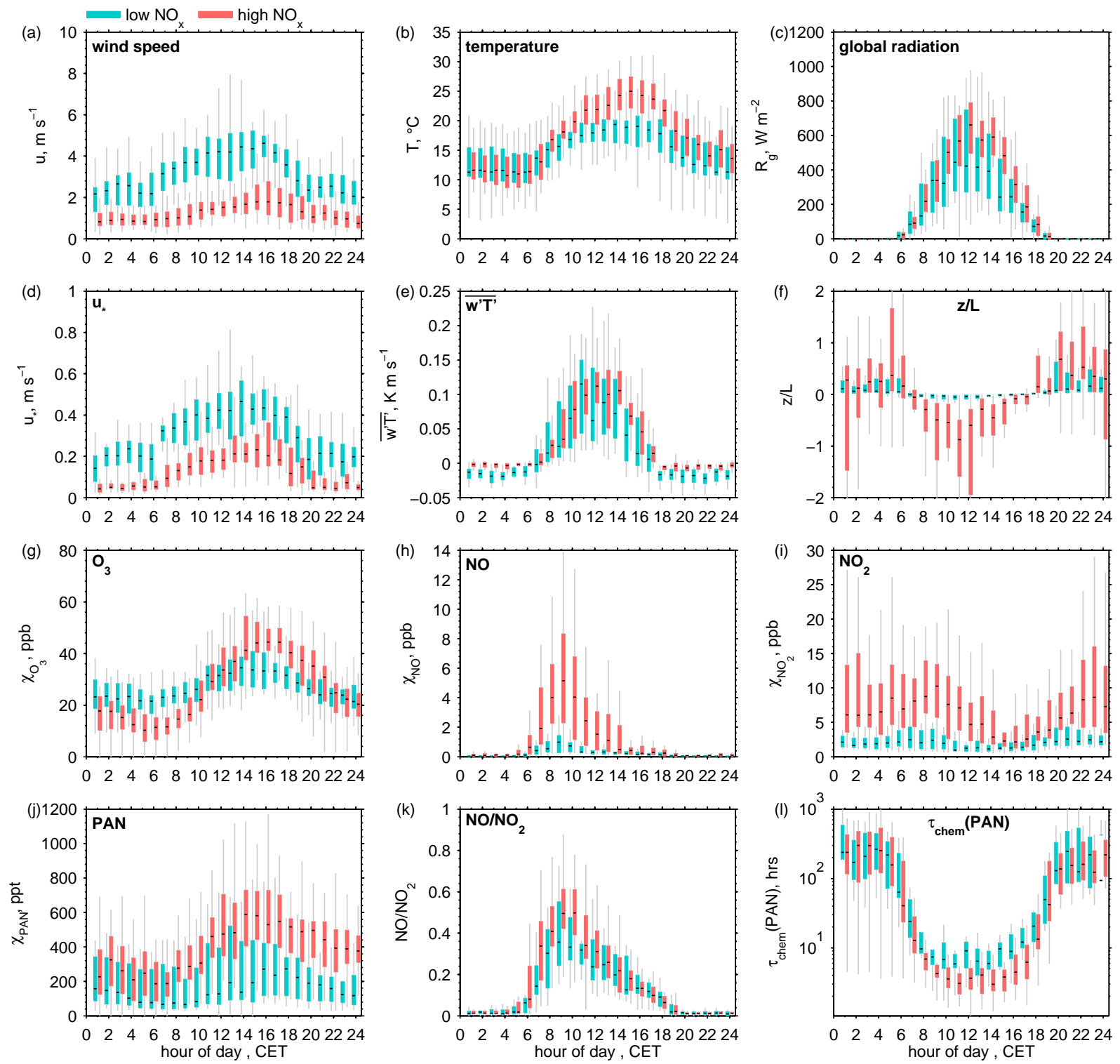

Figure 2. Diurnal boxplot statistics for the period from 29 June to 21 October 2011 at the Mainz Finthen grassland site, characterizing low and high $\mathrm{NO}_{\mathrm{x}}$ periods according to the prevailing meteorological conditions (a-f), mixing ratios of the $\mathrm{O}_{3}-\mathrm{NO}-\mathrm{NO}_{2}$ triad $(\mathbf{g}-\mathbf{i})$ and $\mathrm{PAN}$ mixing ratios including the $\mathrm{NO} / \mathrm{NO}_{2}$ ratio used for the calculation of $\tau_{\text {chem }}(\mathbf{j}-\mathbf{l})$.

dian $\sim 2 \mathrm{~h}$ ) caused by both on average higher $\mathrm{NO} / \mathrm{NO}_{2}$ ratios in the morning and higher temperatures in the afternoon.

\subsection{Evaluation of PAN flux measurements}

\subsubsection{Deposition fluxes and canopy conductance}

During the period of the PAN flux measurement mainly high $\mathrm{NO}_{\mathrm{x}}$ conditions prevailed. The PAN fluxes showed a clear diurnal cycle with maximum deposition fluxes at midday and very small fluxes during nighttime (Fig. 3). Although the random flux errors were large compared to the observed fluxes (median $\pm 0.035 \mathrm{nmol} \mathrm{m}^{-2} \mathrm{~s}^{-1}$, see Moravek et al., 2014) a daytime PAN deposition was clearly visible on most days. The gaps in the time series are due to extended instrument calibrations and maintenance of the GC-ECD. For the further evaluation, PAN fluxes below the flux detection limit ( $34 \%$ of data, see Sect. 2.2 for definition) were neglected, aside from data where $u_{*}<0.07 \mathrm{~m} \mathrm{~s}^{-1}$ ( $28 \%$ of data) as this criterion would have eliminated most of the nighttime values.

The diurnal median values of the $\mathrm{PAN}$ and $\mathrm{O}_{3}$ fluxes are shown in Fig. 4a-b. A diurnal course of the PAN flux is observed with maximal deposition fluxes of $\sim-0.1 \mathrm{nmol}$ $\mathrm{m}^{-2} \mathrm{~s}^{-1}$ during daytime, which corresponds to $v_{\text {DAN }}$ at $z_{\text {ref }}$ of $\sim 0.3 \mathrm{~cm} \mathrm{~s}^{-1}$. The visible short-term peaks are mostly attributed to the low number of data values $\left(\sum n=\right.$ 


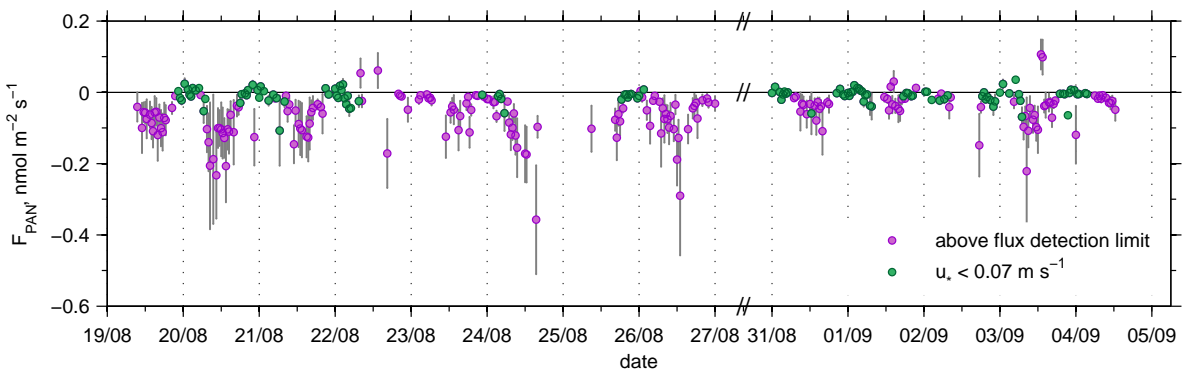

Figure 3. Overview of PAN flux measurements using the MBR method from 19 August to 4 September 2011 at the Mainz Finthen grassland site after applying quality criteria as described in Moravek et al. (2014). Error bars represent the random flux error and green values indicate periods with weak turbulent exchange $\left(u_{*}<0.07 \mathrm{~m} \mathrm{~s}^{-1}\right)$.
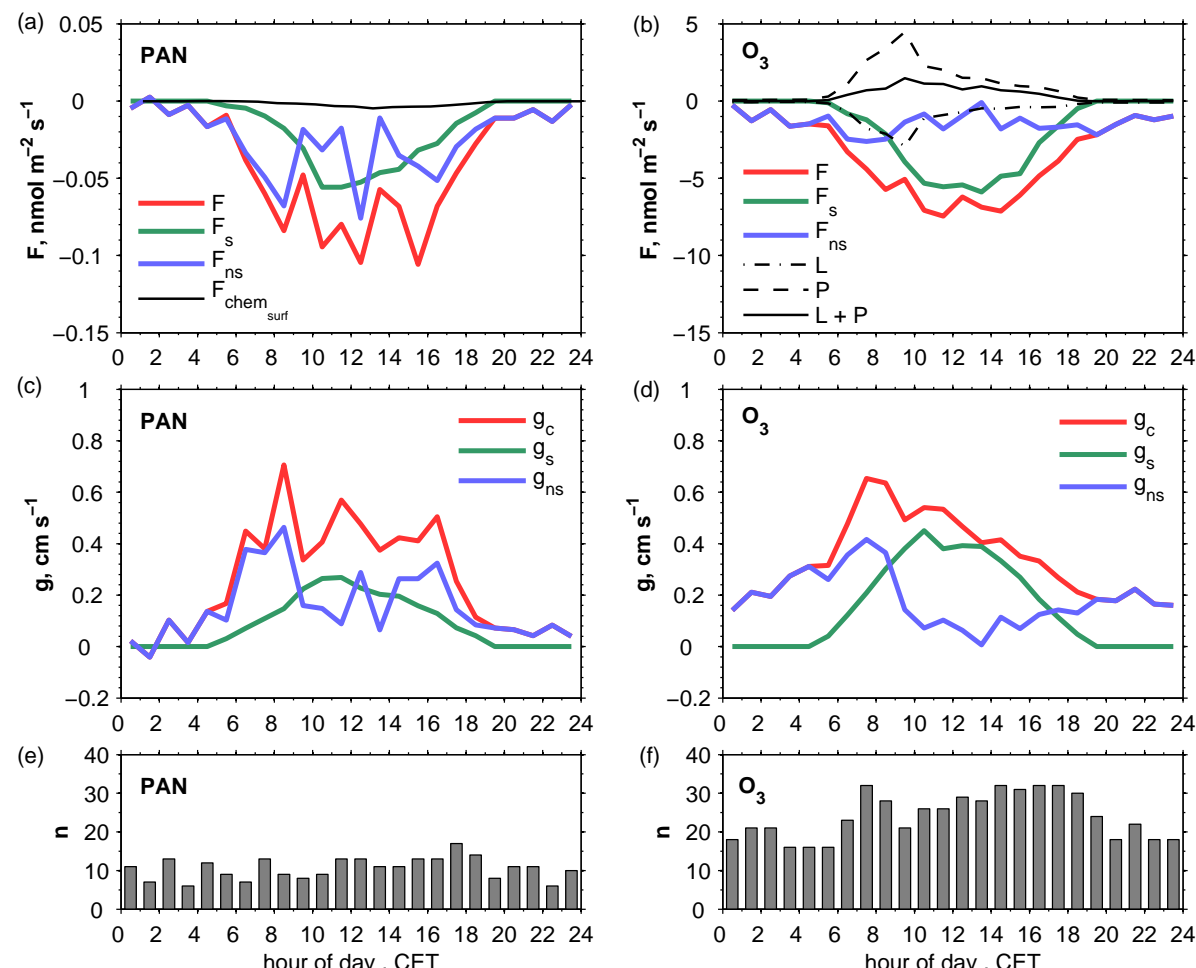

Figure 4. Flux partitioning of PAN (left column) and $\mathrm{O}_{3}$ (right column) deposition into stomatal and non-stomatal pathways at the Mainz Finthen grassland site. Shown are diurnal median values for the period from 19 August to 4 September 2011. Panels (a) and (b) indicate the deposition fluxes including the thermochemical flux term $\left(F_{\text {chem }_{\text {surf }}}\right)$ for PAN and the loss $(\mathrm{L})$ and production $(\mathrm{P})$ terms for $\mathrm{O}_{3}$. Panels (c) and (d) show the respective conductances, while (e) and (f) show the number data points used for every hourly interval.

255) and also caused by the uncertainty of the MBR method. For $\mathrm{O}_{3}$, this feature was much less pronounced due to the higher number of data points used $\left(\sum n=\right.$ $639)$. Both measured PAN fluxes and $v_{\text {DAN }}$ values were between the observations by Wolfe et al. (2009) (midday averages $-0.04 \mathrm{nmol} \mathrm{m}^{-2} \mathrm{~s}^{-1} ; v_{\mathrm{D}} \approx 0.1 \mathrm{~cm} \mathrm{~s}^{-1}$ ) and fluxes by Turnipseed et al. (2006) (midday averages $\sim-0.35 \mathrm{nmol} \mathrm{m}^{-2} \mathrm{~s}^{-1} ; v_{\mathrm{D}} \approx 1 \mathrm{~cm} \mathrm{~s}^{-1}$ ) measured at two different pine forest sites in the USA during summer (Table 1). Daytime flux measurements at a grassland site by Doskey et al. (2004) resulted in an average $v_{D_{\text {PAN }}}$ of $0.13 \mathrm{~cm} \mathrm{~s}^{-1}$. The magnitude of the daytime PAN flux at our site was about two orders of magnitude lower than the $\mathrm{O}_{3}$ flux, yielding a median $v_{\mathrm{D}_{\mathrm{PAN}}} / v_{\mathrm{D}_{\mathrm{O}} 3}$ ratio of 1.03 . Comparison with experimentally derived PAN fluxes in the past (Table 1) reveals that $v_{\mathrm{D}_{\mathrm{PAN}}} / v_{\mathrm{D}_{\mathrm{O}}}$ ratios vary considerably, which might be attributed to a large extent to the error of the applied measurement methods and the assumptions made. It has to be noted that $v_{\mathrm{D}}$ is height dependent, which can make its comparison between different studies difficult. However, the ratio $v_{\mathrm{DPAN}} / v_{\mathrm{D}_{\mathrm{O}_{3}}}$ is largely independent from height in the case 
Table 1. Comparison of PAN fluxes and deposition velocities at the Mainz Finthen grassland with previous studies. All field experiments were performed in the mid-latitudes of the Northern Hemisphere within the period of late spring to early autumn.

\begin{tabular}{|c|c|c|c|c|c|c|c|c|c|}
\hline \multirow[t]{2}{*}{ Method } & \multirow[t]{2}{*}{$\begin{array}{l}\text { Vegetation/ } \\
\text { location }\end{array}$} & \multirow{2}{*}{$\begin{array}{l}\text { LAI } \\
\text { (one } \\
\text { sided) }\end{array}$} & \multicolumn{2}{|c|}{$\begin{array}{l}\text { Flux } \\
\left(\text { nmolm }^{-2} \mathrm{~s}^{-1}\right)\end{array}$} & \multicolumn{2}{|c|}{$\begin{array}{l}v_{\mathrm{D}} \\
\left(\mathrm{cms}^{-1}\right)\end{array}$} & \multicolumn{2}{|c|}{$\begin{array}{l}v_{\mathrm{D}_{\mathrm{PAN}}} / v_{\mathrm{D}_{\mathrm{O}_{3}}} \\
(-)\end{array}$} & \multirow[t]{2}{*}{ Study } \\
\hline & & & day & night & day & night & day & night & \\
\hline \multirow[t]{2}{*}{ EC (CIMS) } & pine forest & 3.5 & -0.35 & -0.05 & $\sim 0.7$ & $\sim 0.3$ & - & $>1$ & Turnipseed et al. (2006) \\
\hline & pine forest & 5.1 & -0.04 & -0.03 & 0.30 & 0.10 & 1.25 & 0.5 & Wolfe et al. (2009) ${ }^{\mathrm{a}}$ \\
\hline \multirow[t]{3}{*}{ Gradient/MBR } & corn field & - & - & - & - & 0.54 & - & - & Schrimpf et al. (1996) \\
\hline & grassland & - & - & - & 0.13 & - & $0.2-0.3$ & - & Doskey et al. (2004) \\
\hline & grassland & 4.8 & -0.07 & -0.01 & 0.30 & 0.06 & 1.03 & 1.25 & this study \\
\hline \multirow[t]{4}{*}{ NBLB } & n.s. & - & - & - & - & - & - & 0.31 & Garland and Penkett (1976) \\
\hline & forest, agric. & - & - & - & - & - & - & 2.38 & Shepson et al. $(1992)^{\mathrm{b}}$ \\
\hline & rural, sea-side & - & - & - & - & - & - & $1.1-6.2$ & McFadyen and Cape (1999) \\
\hline & grassland & 4.8 & - & - & - & - & - & 1.75 & this study (see Sect. 3.3.3) \\
\hline \multirow[t]{4}{*}{ Laboratory } & alfalfa & - & \multicolumn{2}{|c|}{-} & \multicolumn{2}{|c|}{ - } & \multicolumn{2}{|c|}{0.37} & Hill (1971) \\
\hline & grass & - & \multicolumn{2}{|c|}{ - } & \multicolumn{2}{|c|}{0.25} & \multicolumn{2}{|c|}{0.5} & Garland and Penkett (1976) \\
\hline & trees, crops & - & \multirow{2}{*}{\multicolumn{2}{|c|}{$\begin{array}{l}-0.02 \text { to }-0.06 \\
-0.01 \text { to }-0.02\end{array}$}} & \multirow{2}{*}{\multicolumn{2}{|c|}{$\begin{array}{l}0.00-1.50 \\
0.11-0.34\end{array}$}} & \multicolumn{2}{|c|}{-} & Sparks et al. (2003) \\
\hline & trees, herb. & - & & & & & \multicolumn{2}{|c|}{ - } & Teklemariam and Sparks (2004) \\
\hline
\end{tabular}

a Net flux; in-canopy production of PAN was observed.

${ }^{\mathrm{b}} \mathrm{O}_{3}$ flux not was not measured directly.

that the vertical profiles of PAN and $\mathrm{O}_{3}$ concentrations are similar as was shown at least for the data from our site.

The chemical flux divergence between $z_{\text {ref }}$ and $z_{0}$ due to thermochemical decomposition of PAN (Eq. 6) was found to be very small with the highest median value of $0.007 \mathrm{nmol} \mathrm{m}^{-2} \mathrm{~s}^{-1}$ at noon (Fig. 4a). In contrast, for the $\mathrm{O}_{3}$ flux, the loss term due to reaction with $\mathrm{NO}$ and the production by $\mathrm{NO}_{2}$ photolysis were significantly higher between 06:00 and 11:00 CET and led to a small net production of $\mathrm{O}_{3}$ during daytime, which was corrected for in the presented fluxes.

The overall canopy conductance for PAN $\left(g_{\text {CPAN }}\right)$, representing the flux normalized by the concentration at $z_{0}$, shows a mean diurnal cycle with its maximum during daytime (Fig. 4c-d). The midday median values were around $0.4 \mathrm{~cm} \mathrm{~s}^{-1}$ and were similar to $g_{\mathrm{c}}$ values observed for $\mathrm{O}_{3}$.

\subsubsection{Stomatal uptake}

During nighttime $g_{\text {SPAN }}$ values were zero due to stomata closure (Fig. 4c). With the onset of radiation in the morning $g_{\mathrm{SPAN}}$ increases and reaches its maximum of $0.26 \mathrm{~cm} \mathrm{~s}^{-1}$ at 11:00 CET. As both $g_{\mathrm{SPAN}_{\mathrm{P}}}$ and $g_{\mathrm{S}_{\mathrm{O}_{3}}}$ differ only by the PAN and $\mathrm{O}_{3}$ diffusivities (see Sect. 2.4), they show the same pattern, while $g_{\mathrm{S}_{3}}$ is larger by a factor of 1.6 due to the faster diffusivity of $\mathrm{O}_{3}$. Due to an increased vapour pressure deficit in the afternoon the maximum values of $g_{\mathrm{SPAN}_{\mathrm{PN}}}$ and $g_{\mathrm{S}_{3}}$ are slightly skewed towards the morning.

The existence of a mesophyllic resistance limiting the stomatal uptake of PAN, as was found by Teklemariam and Sparks (2004) or by Sparks et al. (2003) at high stomatal conductance, cannot be validated from our data. Only if the modelled $g_{\mathrm{SAN}}$ values exceeded the experimentally determined $g_{\text {CPAN }}$ values, could a limitation be suspected. It is suggested that the mesophyllic uptake of PAN is lower than for $\mathrm{O}_{3}$, as there are fewer reaction sites for PAN within the plant cell and its reaction with proteins is slower, although the mesophyll biochemistry for PAN assimilation is not clearly understood (Doskey et al., 2004).

\subsubsection{Non-stomatal deposition}

According to the MBR flux measurements at our site, the non-stomatal sink played a major role with median midday $g_{\text {nspaN }}$ values ranging between 0.05 and $0.4 \mathrm{~cm} \mathrm{~s}^{-1}$, corresponding to a non-stomatal resistance $\left(R_{\mathrm{ns}}=g_{\mathrm{ns}}^{-1}\right)$ of 2000 and $240 \mathrm{~s} \mathrm{~m}^{-1}$, respectively. The nighttime $g_{\mathrm{ns} \text { PAN }}$ values are very low, but have to be treated with caution due to the uncertainties of the MBR method at night. The peaks in $g_{\text {nSPAN }}$ are mainly associated with the uncertainties of $g_{\mathrm{CPAN}}$ caused by the limited amount of data (see Sect. 3.3.1). For $\mathrm{O}_{3}$, we observed a clear diurnal cycle with lowest values in the afternoon. The diurnal cycle could be well reproduced as a function of relative humidity multiplied by LAI, despite elevated values between 06:00 and 10:00 CET, where surface humidity is still very high and the $\mathrm{NO}_{\mathrm{x}}$ advection might lead to a greater uncertainty of the chemical production and loss of terms (Sect. 3.3.1).

Since uncertainties in the $\mathrm{O}_{3}$ flux impact the PAN flux directly, we discarded data with large $\mathrm{NO}_{\mathrm{x}}$ values for the evaluation of $g_{\mathrm{n} \text { PAN }}$ as well as values where $u_{*}<0.07 \mathrm{~m} \mathrm{~s}^{-1}$. We could not identify any significant dependency of the individual data points of $g_{\mathrm{ns}}$ on temperature, relative humidity or surface wetness. This contradicts the assumption of Shepson et al. (1992), who suspected that $g_{\text {nspaN }}$ would decrease 
with higher surface wetness due to the low deposition on water surfaces (Kames et al., 1991). Turnipseed et al. (2006) explained a maximum of $v_{\text {DPAN }}$ after sunrise with increased deposition to leaf surface water of a pine forest canopy and hypothesize the existence of a reactive uptake process within the leaf water. However, our findings support the results by Schrimpf et al. (1996), who did not observe a relationship of $g_{\text {nspan }}$ with relative humidity.

For the determination of $F_{\text {modelpan }}$ over the entire measurement period (see Sect. 2.4) an estimate or parameterization of $g_{\text {nspan }}$ is required. Since from our data, no significant dependency was found and nighttime values are uncertain, we assume a constant value of $g_{\text {nspaN }}$. Hence, we derived a bulk $g_{\text {ns }}$ val value by correlating the measured PAN fluxes with a modelled PAN flux using a series of different $g_{\text {ns PAN }}$ values in Eq. (2). The smallest root mean square error was obtained with an optimal $g_{\mathrm{ns}}$ value of $0.28 \mathrm{~cm} \mathrm{~s}^{-1}$ for the whole data set, which corresponds to $R_{\mathrm{nSPAN}}=360 \mathrm{~s} \mathrm{~m}^{-1}$. This resistance value is in the range of findings by other studies - e.g. Turnipseed et al. (2006) observed a median value of $244 \mathrm{~s} \mathrm{~m}^{-1}$ under dry and $125 \mathrm{~s} \mathrm{~m}^{-1}$ under wet conditions.

To obtain another independent estimate of the nonstomatal deposition, we employed the nocturnal boundary layer budget (NBLB) method according to Shepson et al. (1992), which compares the nocturnal PAN decay to that of $\mathrm{O}_{3}$ and yields a ratio of PAN to $\mathrm{O}_{3}$ deposition velocities. The main assumption, that the decline of both PAN and $\mathrm{O}_{3}$ mixing ratio during nighttime was only due to deposition, is valid as chemical reactions are negligible at night for both PAN (see Fig. 21) and $\mathrm{O}_{3}$ (no photolysis and low NO mixing ratios). We analysed in total 16 nights, where a clear logarithmic decline of both PAN and $\mathrm{O}_{3}$ mixing ratios was observed and where the main wind direction was within the "clean" sector in the southwest. Using only nights with a good correlation between both PAN and $\mathrm{O}_{3}$ decline $\left(R^{2}>0.7\right)$, we obtain an average value for $v_{\mathrm{D}_{\mathrm{PAN}}} / v_{\mathrm{D}_{\mathrm{O}_{3}}}$ of 1.75 , which is similar to the average value obtained by Shepson et al. (1992). As stomatal uptake is assumed to be zero at night, we obtained according to Eq. (3) a bulk $g_{\text {ns }}$ of $0.5 \mathrm{~cm} \mathrm{~s}^{-1}\left(R_{\mathrm{nSPAN}}=200 \mathrm{~s} \mathrm{~m}^{-1}\right)$. This value of $g_{\text {nSPAN }}$ is slightly larger than the value obtained from the MBR measurement.

In currently applied deposition models (e.g. Simpson et al., 2012), $g_{\text {nspan }}$ is often derived according to Wesely (1989) as a composite between the non-stomatal conductance of sulfur dioxide $\left(g_{\mathrm{ns}_{2}}\right)$ and $g_{\mathrm{ns}_{3}}$ :

$g_{\mathrm{nSPAN}}=10^{-5} \cdot H_{\mathrm{PAN}}^{*} \cdot g_{\mathrm{ns}_{\mathrm{SO}_{2}}}+f_{0_{\mathrm{PAN}}} \cdot g_{\mathrm{ns}_{\mathrm{O}_{3}}}$.

$\mathrm{SO}_{2}$ represents a very soluble substance (effective Henry constant $H_{\mathrm{SO}_{2}}^{*}=10^{5} \mathrm{M} \mathrm{atm}^{-1}$ ) and $\mathrm{O}_{3}$ a compound that reacts fast with substances in the leaf cuticles such as protein thiols (Mudd, 1982). Due to the poor solubility of PAN in water $\left(H_{\mathrm{PAN}}^{*}=4.1 \mathrm{M} \mathrm{atm}^{-1}\right.$, see Kames and Schurath, 1995) the first term of the right-hand side of Eq. (9) can be ne- glected and only the reactivity index, $f_{0}$, is of significant importance. According to Wesely (1989) $f_{0_{\mathrm{PAN}}}=0.1$, which suggests the non-stomatal deposition of PAN would be about one order of magnitude lower than for $\mathrm{O}_{3}$. Zhang et al. (2002) suggest a $f_{0 \mathrm{PAN}}=0.6$ based on first studies on PAN deposition by Hill (1971) and Garland (1977). This contradicts our findings by both the MBR and the NBLB method, which observed at least equal or even higher non-stomatal deposition for PAN than for $\mathrm{O}_{3}$, and supports the statement by Turnipseed et al. (2006) that current deposition models may significantly underestimate PAN non-stomatal deposition.

\subsection{PAN deposition fluxes for low and high $\mathrm{NO}_{\mathbf{x}}$ conditions}

To evaluate the PAN deposition under both low and high $\mathrm{NO}_{\mathrm{x}}$ conditions as well as its potential influence on the natural grassland ecosystem and its role for the atmospheric $\mathrm{N}_{\mathrm{r}}$ budget, the PAN deposition flux was modelled for the entire period from 29 June to 21 October (see Sect. 2.4). For this, we used the bulk value for $g_{\text {nsPan }}$ of $0.28 \mathrm{~cm} \mathrm{~s}^{-1}$ (Sect. 3.3.3) for both low and high $\mathrm{NO}_{\mathrm{x}}$, as we found this to be the best estimate from our data. The obtained median diurnal cycles of $F_{\text {modelpan }}$ for low and high $\mathrm{NO}_{\mathrm{x}}$ conditions (Fig. 5) reveal that the total deposition (i.e. stomatal + non-stomatal) was more than twice as high during high $\mathrm{NO}_{\mathrm{x}}\left(\sim-0.1 \mathrm{nmol} \mathrm{m}{ }^{-2} \mathrm{~s}^{-1}\right)$ than during low $\mathrm{NO}_{\mathrm{x}}$ $\left(\sim-0.05 \mathrm{nmol} \mathrm{m}^{-2} \mathrm{~s}^{-1}\right)$ conditions, which is mainly attributed to the higher PAN mixing ratios during high $\mathrm{NO}_{\mathrm{x}}$ conditions. Median midday deposition velocities were very similar during both episodes $\left(v_{\mathrm{D}_{\mathrm{PAN}}} \approx 0.5 \mathrm{cms}^{-1}\right)$. As already discussed in Sect. 3.3.3, the non-stomatal pathway was significant, which is reflected by a daytime fraction of $g_{\text {nsPAN }} / g_{\text {CPAN }}$ of 0.7 during low $\mathrm{NO}_{\mathrm{x}}$ and 0.6 during high $\mathrm{NO}_{\mathrm{x}}$ conditions. As about half of the grassland vegetation was senescent or was already dead, reaction on plant surfaces may be a reason for the large non-stomatal fraction.

The importance of PAN deposition as a loss process of PAN from the atmosphere is determined by comparison to the magnitude of the thermochemical decomposition of PAN in the boundary layer (Eq. 7). Due to the lower temperatures and the lack of NO at night, the nocturnal thermochemical loss was insignificant during both low and high $\mathrm{NO}_{\mathrm{x}}$ conditions. Using the boundary layer budget approach (Eq. 8), we found $h_{\mathrm{BL} \_ \text {night }}$ to be on average $200 \mathrm{~m}$ (Fig. 5). In contrast, during daytime the thermochemical loss constituted the largest PAN sink, during both low and high $\mathrm{NO}_{\mathrm{x}}$ conditions. After dawn, $h_{\mathrm{BL} \_ \text {day }}$ grew during high $\mathrm{NO}_{\mathrm{x}}$ conditions on average up to $1200 \mathrm{~m}$, whereas its development was slightly suppressed during low $\mathrm{NO}_{\mathrm{x}}$ conditions. The modelled boundary layer height was compared for selected days to the boundary layer height obtained from a WRF model. The WRF model yielded slightly higher daytime maximum values ranging from 1100 up to $1700 \mathrm{~m}$. When the boundary was well mixed (11:00-17:00 CET), the thermochemical 

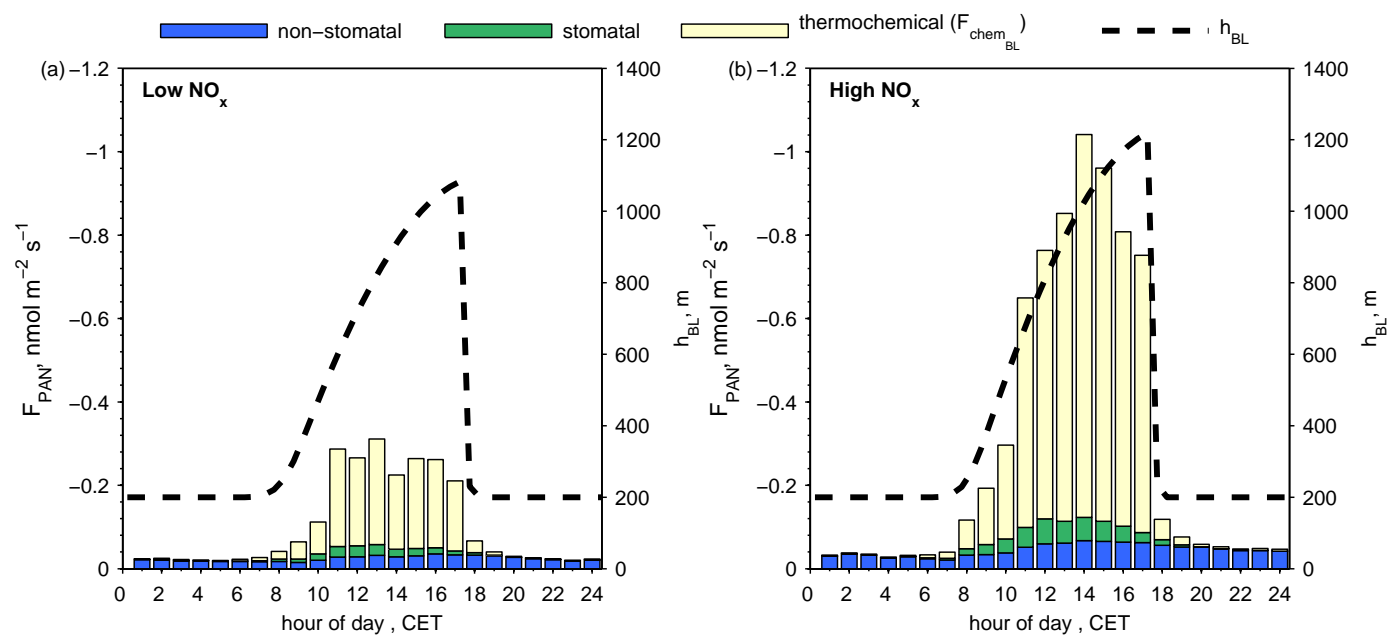

Figure 5. Modelled stomatal and non-stomatal PAN deposition fluxes and PAN loss due to thermochemical decomposition for (a) low and (b) high $\mathrm{NO}_{\mathrm{x}}$ periods at the Mainz Finthen grassland site. The dashed line marks the theoretical boundary layer height used for the calculation of the PAN decomposition (for details see text).

loss during high $\mathrm{NO}_{\mathrm{x}}$ conditions was about 3.5 times higher than during low $\mathrm{NO}_{\mathrm{x}}$ conditions. This was caused by a combination of (a) the higher PAN mixing ratios (effect: $59 \%$ ), (b) the reduced reaction timescale due to higher temperatures and larger $\mathrm{NO}$ to $\mathrm{NO}_{2}$ ratios (effect: $34 \%$ ) and to some extent also by (c) the higher boundary layer (effect: $7 \%$ ). A summary of the relevant parameters for nighttime and daytime conditions is given in Table 2 , where the timescale for PAN deposition is given by $\tau_{\text {dep }}=\rho_{\mathrm{m}} \cdot \chi_{\mathrm{PAN}} \cdot F_{\text {model }}^{-1} \cdot h_{\mathrm{BL}}$. The reaction rates towards PAN deposition $\left(k_{\mathrm{dep}}\right)$ and thermochemical decomposition over the entire boundary layer height $\left(k_{\mathrm{chem}}{ }_{\mathrm{BL}}\right)$ are the inverse values of $\tau_{\mathrm{dep}}$ and $\tau_{\mathrm{chem}}$, respectively.

Integrating $F_{\text {model }_{\text {PAN }}}$ and $F_{\text {chem }}$ BL over the entire diel cycle yields the total mass of PAN removed per unit area by dry deposition $\left(L_{\mathrm{dep}}\right)$ and thermochemical decomposition $\left(L_{\text {chem }}\right)$, respectively (McFadyen and Cape, 1999; Turnipseed et al., 2006). As presented in Table 2, during low $\mathrm{NO}_{\mathrm{x}}$ conditions dry deposition made up $32 \%$, whereas under high $\mathrm{NO}_{\mathrm{x}}$ conditions it contributed with $22 \%$. to the diurnal PAN removal within the boundary layer. These values are slightly lower than the ones given by McFadyen and Cape (1999), who suggest equal PAN loss via both processes. Although they claim very low $\mathrm{NO} / \mathrm{NO}_{2}$ ratios at the site to be a major reason for the low chemical loss, an overestimation of the PAN deposition in their study is possible, since it was not measured directly. Accounting for a temperature decrease with height, Turnipseed et al. (2006) estimated a maximal contribution of dry deposition of $10 \%$. Wolfe et al. (2009) found that dry deposition accounted only for $3 \%$ of the total PAN loss during warm and $13 \%$ during cool periods.

To evaluate its significance as a source of $\mathrm{N}_{\mathrm{r}}$ to the grassland ecosystem, PAN deposition has to be evaluated in relation to other $\mathrm{N}_{\mathrm{r}}$ sources. Dennis et al. (2013) estimate a contribution of dry deposition of PANs (i.e. the sum of all PAN species) of about $3.5 \%$ to the total dry and wet nitrogen annual deposition in the continental USA. However, their values are based on the parameterization by Zhang et al. (2002), which might significantly underestimate dry deposition of PAN as found e.g. by Turnipseed et al. (2006) and in this study. Stevens et al. (2010) evaluated the effect of total inorganic nitrogen deposition on grasslands across Europe and found that species richness decreased with sites that were subject to higher nitrogen deposition. The observed PAN removal via dry deposition (i.e. $L_{\text {dep }}$ ) over an entire day was in this study $333 \mu \mathrm{g} \mathrm{m}^{-2} \mathrm{~d}^{-1}$ during low and $518 \mu \mathrm{g} \mathrm{m}^{-2} \mathrm{~d}^{-1}$ during high $\mathrm{NO}_{\mathrm{x}}$ conditions (Table 2). This is much lower than the total nitrogen deposition observed at the sites reported by Stevens et al. (2010) ranging between 4.7 and $104.2 \mu \mathrm{g} \mathrm{m}^{-2} \mathrm{~d}^{-1}$ (equivalent to 2 and $44 \mathrm{~kg} \mathrm{Nha}^{-1} \mathrm{a}^{-1}$ ), which suggests that PAN deposition under both low and high $\mathrm{NO}_{\mathrm{x}}$ does not play a critical role on plant species richness at our site. Moreover, PAN mixing ratios observed at our site were significantly below the threshold given for phytotoxic effect on plants (between 15 and 25 ppb, see Temple and Taylor, 1983).

\section{Conclusions}

To date, very few studies have directly measured PAN deposition to ecosystems. Previous experiments often cover only a short time period and obtained results differ considerably. In particular, the relationship between PAN and $\mathrm{O}_{3}$ deposition has remained inconclusive. Based on the MBR method, we find a considerable non-stomatal uptake of PAN $\left(g_{\text {nspaN }}=0.28 \mathrm{~cm} \mathrm{~s}^{-1}\right)$. This resulted in an equal or even higher non-stomatal conductance for PAN than for $\mathrm{O}_{3}$, most 
Table 2. Modelled PAN deposition and thermochemical loss for low and high $\mathrm{NO}_{\mathrm{x}}$ conditions at the Mainz Finthen grassland site. The description of the shown parameters is given in the text.

\begin{tabular}{|c|c|c|c|c|c|c|c|c|c|c|c|}
\hline & $\begin{array}{l}\text { PAN } \\
\text { (ppt) }\end{array}$ & $\begin{array}{l}T \\
\left({ }^{\circ} \mathrm{C}\right)\end{array}$ & $\begin{array}{l}\mathrm{NO} / \mathrm{NO}_{2} \\
(-)\end{array}$ & $\begin{array}{l}h_{\mathrm{BL}} \\
(\mathrm{m})\end{array}$ & $\begin{array}{l}\tau_{\text {dep }} \\
\text { (d) }\end{array}$ & $\begin{array}{l}\tau_{\text {chem }} \text { BL } \\
\text { (d) }\end{array}$ & $\begin{array}{l}k_{\mathrm{dep}} \\
\left(\mathrm{s}^{-1}\right)\end{array}$ & $\begin{array}{l}k_{\mathrm{chem}} \mathrm{BL} \\
\left(\mathrm{s}^{-1}\right)\end{array}$ & $\begin{array}{l}L_{\mathrm{dep}} \\
\left(\mu \mathrm{gm}^{-2} \mathrm{~d}^{-1}\right)\end{array}$ & $\begin{array}{l}L_{\text {chem }_{\mathrm{BL}}} \\
\left(\mu \mathrm{g} \mathrm{m}^{-2} \mathrm{~d}^{-1}\right)\end{array}$ & $\begin{array}{l}L_{\mathrm{dep}} \\
(\%)\end{array}$ \\
\hline $\begin{array}{l}\text { Low } \mathrm{NO}_{\mathrm{x}} \\
\text { daytime } \\
\text { nighttime } \\
\text { all }\end{array}$ & $\begin{array}{l}182 \\
147\end{array}$ & $\begin{array}{l}17.6 \\
13.6\end{array}$ & $\begin{array}{l}0.18 \\
0.01\end{array}$ & $\begin{array}{l}567 \\
200\end{array}$ & $\begin{array}{l}1.50 \\
0.42\end{array}$ & $\begin{array}{l}0.88 \\
16.08\end{array}$ & $\begin{array}{l}1.8 \times 10^{-4} \\
6.7 \times 10^{-4}\end{array}$ & $\begin{array}{l}3.2 \times 10^{-4} \\
0.17 \times 10^{-4}\end{array}$ & 333 & 698 & 32 \\
\hline $\begin{array}{l}\text { High } \mathrm{NO}_{\mathrm{x}} \\
\text { daytime } \\
\text { nighttime } \\
\text { all }\end{array}$ & $\begin{array}{l}405 \\
334\end{array}$ & $\begin{array}{l}20.0 \\
15.9\end{array}$ & $\begin{array}{l}0.23 \\
0.01\end{array}$ & $\begin{array}{l}641 \\
200\end{array}$ & $\begin{array}{l}1.54 \\
0.83\end{array}$ & $\begin{array}{l}0.54 \\
12.67\end{array}$ & $\begin{array}{l}1.8 \times 10^{-4} \\
3.3 \times 10^{-4}\end{array}$ & $\begin{array}{l}5.1 \times 10^{-4} \\
0.21 \times 10^{-4}\end{array}$ & 518 & 1840 & 22 \\
\hline
\end{tabular}

likely suggesting an underestimation of PAN deposition by current models. We did not find a relation of the non-stomatal conductance for PAN with other quantities, such as relative humidity. However, it cannot be fully excluded that this may also be attributed to the limited PAN flux data above the flux detection limit. The modelled stomatal uptake did not exceed the overall deposition, suggesting that stomatal uptake is not limited by further, not-considered resistances.

PAN deposition at our measurement site was governed by two contrasting pollution regimes: (1) low $\mathrm{NO}_{\mathrm{x}}$ episodes with clean air from southwesterly directions and (2) high $\mathrm{NO}_{\mathrm{x}}$ episodes with more polluted air masses from the northeastern sector. Under high $\mathrm{NO}_{\mathrm{x}}$ conditions, locally produced PAN from the industrialized region was advected to the site, leading to PAN mixing ratios which were a factor of 2-4 higher than under low $\mathrm{NO}_{\mathrm{x}}$ conditions. Hence, PAN deposition during these episodes was larger with daytime maxima of $-0.1 \mathrm{nmol} \mathrm{m}^{-2} \mathrm{~s}^{-1}$. However, as also found in previous studies, the largest fraction of PAN loss during daytime was due to thermochemical decomposition of PAN. For clean conditions dry deposition accounted for about $32 \%$ of the daytime PAN loss, while it only accounted for $22 \%$ during polluted conditions. The higher thermochemical PAN loss during polluted episodes was mainly associated with different meteorological conditions and only to some extent caused by larger $\mathrm{NO} / \mathrm{NO}_{2}$ ratios, due to freshly emitted $\mathrm{NO}$ by nearby sources. During nighttime non-stomatal PAN deposition was the only significant PAN sink.

A comparison of PAN deposition at the site with other deposition pathways of atmospheric reactive nitrogen suggests that PAN deposition only played a minor role as a potential nitrogen source to the nutrient-poor natural grassland ecosystems in this study. However, to date still little is known about the direct uptake of PAN by vegetation and the effect on their metabolism. Furthermore, studies which performed direct PAN flux measurements are limited to only a few types of ecosystems and conditions, and are often prone to large uncertainties. As suggested by other studies in the past, PAN deposition might be the dominant removal process of atmo- spheric PAN in winter at lower temperatures. However, to date in situ PAN flux measurements only cover late spring to early autumn periods in the Northern Hemisphere. Hence, both in situ flux measurements of PAN during different seasons and for a larger variety of ecosystems as well as detailed studies on the role of non-stomatal uptake mechanisms to improve current deposition models are desirable tasks for future research on PAN deposition.

Acknowledgements. This project was funded by the Max Planck Society. J.-C. Mayer and D. Plake contributed to the setup and operation of additional measurements at the field site. L. Smoydzin applied the WRF model for the estimation of the boundary layer height. We thank C. Ammann and D. Plake for discussion on the flux divergence and chemical correction methods.

The service charges for this open access publication have been covered by the Max Planck Society.

Edited by: J. Roberts

\section{References}

Brown, S. S. and Stutz, J.: Nighttime radical observations and chemistry, Chem. Soc. Rev., 41, 6405-6447, doi:10.1039/c2cs35181a, 2012.

Businger, J. A.: Evaluation of the accuracy with which dry deposition can be measured with current micrometeorological techniques, J. Clim. Appl. Meteorol., 25, 1100-1124, doi:10.1175/1520-0450(1986)025<1100:Eotaww>2.0.Co;2, 1986.

Cazorla, M. and Brune, W. H.: Measurement of Ozone Production Sensor, Atmos. Meas. Tech., 3, 545-555, doi:10.5194/amt3-545-2010, 2010.

De Bruin, H. A. R. and Moore, C. J.: Zero-plane displacement and roughness length for tall vegetation, derived from a simple mass conservation hypothesis, Bound.-Lay. Meteorol., 31, 3949, doi:10.1007/BF00120033, 1985. 
Dennis, R. L., Schwede, D. B., Bash, J. O., Pleim, J. E., Walker, J. T., and Foley, K. M.: Sensitivity of continental United States atmospheric budgets of oxidized and reduced nitrogen to dry deposition parametrizations, Philos. T. R. Soc. B, 368, 20130124, doi:10.1098/rstb.2013.0124, 2013.

Doskey, P. V., Kotamarthi, V. R., Fukui, Y., Cook, D. R., Breitbeil, F. W., and Wesely, M. L.: Air-surface exchange of peroxyacetyl nitrate at a grassland site, J. Geophys. Res.-Atmos., 109, D10310, doi:10.1029/2004jd004533, 2004.

EUROSTAT: Agricuture and Fishery Statistics: Main Results 2009_ 10, 2011 edn., Publications Office of the European Union, Luxembourg, 152 pp., doi:10.2785/15223, 2011.

Foken, T. and Wichura, B.: Tools for quality assessment of surfacebased flux measurements, Agr. Forest Meteorol., 78, 83-105, doi:10.1016/0168-1923(95)02248-1, 1996.

Foken, T., Leuning, R., Oncley, S., Mauder, M., and Aubinet, M.: Corrections and data quality control, in: Eddy Covariance edited by: Aubinet, M., Vesala, T., and Papale, D., Springer, Dordrecht, Heidelberg, London, New York, 85-131, 2012.

Garland, J. A.: The dry deposition of sulphur dioxide to land and water surfaces, P. Roy. Soc. Lond. A Mat., 354, 245-268, doi:10.1098/rspa.1977.0066, 1977.

Garland, J. A. and Penkett, S. A.: Absorption of peroxy acetyl nitrate and ozone by natural surfaces, Atmos. Environ., 10, 11271131, doi:10.1016/0004-6981(76)90122-0, 1976.

Hicks, B. B., Baldocchi, D. D., Meyers, T. P., Hosker, R. P., and Matt, D. R.: A preliminary multiple resistance routine for deriving dry deposition velocities from measured quantities, Water Air Soil Poll., 36, 311-330, doi:10.1007/bf00229675, 1987.

Hill, A. C.: Vegetation - sink for atmospheric pollutants, J. Air Pollut. Control Assoc., 21, 341-346, doi:10.1080/00022470.1971.10469535, 1971.

Kames, J. and Schurath, U.: Henrys Law and hydrolysis-rate constants for peroxyacyl nitrates (PANS) using a homogeneous gas-phase source, J. Atmos. Chem., 21, 151-164, doi:10.1007/Bf00696578, 1995.

Kames, J., Schweighoefer, S., and Schurath, U.: Henrys Law constant and hydrolysis of peroxyacetyl nitrate (PAN), J. Atmos. Chem., 12, 169-180, doi:10.1007/Bf00115778, 1991.

Lamaud, E., Loubet, B., Irvine, M., Stella, P., Personne, E., and Cellier, P.: Partitioning of ozone deposition over a developed maize crop between stomatal and non-stomatal uptakes, using Eddycovariance flux measurements and modelling, Agr. Forest Meteorol., 149, 1385-1396, doi:10.1016/j.agrformet.2009.03.017, 2009.

Liu, H. P. and Foken, T.: A modified Bowen ratio method to determine sensible and latent heat fluxes, Meteorol. Z., 10, 71-80, doi:10.1127/0941-2948/2001/0010-0071, 2001.

Mauder, M. and Foken, T.: Documentation and Instruction Manual of the Eddy-Covariance Software Package TK3, Arbeitsergebnisse, Abteilung Mikrometeorologie, Universität Bayreuth, Bayreuth, 60 pp., ISSN 1614-8916, 2011.

McFadyen, G. G. and Cape, J. N.: Physical and chemical influences on PAN concentrations at a rural site, Atmos. Environ., 33, 29292940, doi:10.1016/s1352-2310(99)00095-3, 1999.

Moravek, A., Trebs, I., and Foken, T.: Effect of imprecise lag time and high-frequency attenuation on surface-atmosphere exchange fluxes determined with the relaxed eddy accumula- tion method, J. Geophys. Res.-Atmos., 118, 10210-10224, doi:10.1002/jgrd.50763, 2013.

Moravek, A., Foken, T., and Trebs, I.: Application of a GCECD for measurements of biosphere-atmosphere exchange fluxes of peroxyacetyl nitrate using the relaxed eddy accumulation and gradient method, Atmos. Meas. Tech., 7, 2097-2119, doi:10.5194/amt-7-2097-2014, 2014.

Mudd, J. B.: Effects of oxidants on metabolic function, in: Effects of Gaseous Air Pollution in Agriculture and Horticulture, edited by: Unsworth, M. H. and Ormrod, D. P. (Eds.), ButterworthHeinemann, Woburn, Mass., 189-203, 1982.

Okano, K., Tobe, K., and Furukawa, A.: Foliar uptake of peroxyacetyl nitrate (PAN) by herbaceous species varying in susceptibility to this pollutant, New Phytol., 114, 139-145, doi:10.1111/j.1469-8137.1990.tb00384.x, 1990.

Orlando, J. J., Tyndall, G. S., and Calvert, J. G.: Thermaldecomposition pathways for peroxyacetyl nitrate (PAN) - implications for atmospheric methyl nitrate levels, Atmos. Environ. A-Gen., 26, 3111-3118, doi:10.1016/0960-1686(92)90468Z, 1992.

Oswald, R., Behrendt, T., Ermel, M., Wu, D., Su, H., Cheng, Y., Breuninger, C., Moravek, A., Mougin, E., Delon, C., Loubet, B., Pommerening-Roser, A., Sorgel, M., Poschl, U., Hoffmann, T., Andreae, M. O., Meixner, F. X., and Trebs, I.: HONO emissions from soil bacteria as a major source of atmospheric reactive nitrogen, Science, 341, 1233-1235, doi:10.1126/science.1242266, 2013.

Plake, D., Stella, P., Moravek, A., Mayer, J.-C., Ammann, C., Held, A., and Trebs, I.: Comparison of ozone fluxes measured with the dynamic chamber and the eddy covariance method and partitioning between stomatal and non stomatal deposition, Agr. Forest Meteorol., in review, 2015.

Rannik, U., Aubinet, M., Kurbanmuradov, O., Sabelfeld, K. K., Markkanen, T., and Vesala, T.: Footprint analysis for measurements over a heterogeneous forest, Bound.-Lay. Meteorol., 97, 137-166, doi:10.1023/a:1002702810929, 2000.

Roberts, J. M., Parrish, D. D., Norton, R. B., Bertman, S. B., Holloway, J. S., Trainer, M., Fehsenfeld, F. C., Carroll, M. A., Albercook, G. M., Wang, T., and Forbes, G.: Episodic removal of NOy species from the marine boundary layer over the North Atlantic, J. Geophys. Res.-Atmos., 101, 28947-28960, doi:10.1029/96jd02632, 1996.

Rummel, U., Ammann, C., Kirkman, G. A., Moura, M. A. L., Foken, T., Andreae, M. O., and Meixner, F. X.: Seasonal variation of ozone deposition to a tropical rain forest in southwest Amazonia, Atmos. Chem. Phys., 7, 5415-5435, doi:10.5194/acp-75415-2007, 2007.

Schrimpf, W., Lienaerts, K., Muller, K. P., Rudolph, J., Neubert, R., Schussler, W., and Levin, I.: Dry deposition of peroxyacetyl nitrate $(\mathrm{PAN})$ : determination of its deposition velocity at night from measurements of the atmospheric PAN and (222)Radon concentration gradient, Geophys. Res. Lett., 23, 3599-3602, doi:10.1029/96GL03287, 1996.

Shepson, P. B., Bottenheim, J. W., Hastie, D. R., and Venkatram, A.: Determination of the relative ozone and PAN deposition velocities at night, Geophys. Res. Lett., 19, 1121-1124, doi:10.1029/92GL01118, 1992.

Simpson, D., Benedictow, A., Berge, H., Bergström, R., Emberson, L. D., Fagerli, H., Flechard, C. R., Hayman, G. D., 
Gauss, M., Jonson, J. E., Jenkin, M. E., Nyíri, A., Richter, C., Semeena, V. S., Tsyro, S., Tuovinen, J.-P., Valdebenito, Á., and Wind, P.: The EMEP MSC-W chemical transport model - technical description, Atmos. Chem. Phys., 12, 7825-7865, doi:10.5194/acp-12-7825-2012, 2012.

Singh, H. B.: Reactive nitrogen in the troposphere, Environ. Sci. Technol., 21, 320-327, doi:10.1021/Es00158a001, 1987.

Sparks, J. P., Roberts, J. M., and Monson, R. K.: The uptake of gaseous organic nitrogen by leaves: a significant global nitrogen transfer process, Geophys. Res. Lett., 30, 2189, doi:10.1029/2003g1018578, 2003.

Stella, P., Personne, E., Loubet, B., Lamaud, E., Ceschia, E., Béziat, P., Bonnefond, J. M., Irvine, M., Keravec, P., Mascher, N., and Cellier, P.: Predicting and partitioning ozone fluxes to maize crops from sowing to harvest: the Surfatm- $\mathrm{O}_{3}$ model, Biogeosciences, 8, 2869-2886, doi:10.5194/bg-8-2869-2011, 2011.

Stevens, C. J., Duprè, C., Dorland, E., Gaudnik, C., Gowing, D. J. G., Bleeker, A., Diekmann, M., Alard, D., Bobbink, R., Fowler, D., Corcket, E., Mountford, J. O., Vandvik, V., Aarrestad, P. A., Muller, S., and Dise, N. B.: Nitrogen deposition threatens species richness of grasslands across Europe, Environ. Pollut., 158, 2940-2945, doi:10.1016/j.envpol.2010.06.006, 2010.

Suttie, J. M., Reynolds, S. G., and Batello, C.: Grasslands of the World, FAO, Rome, 2005.

Talukdar, R. K., Burkholder, J. B., Schmoltner, A. M., Roberts, J. M., Wilson, R. R., and Ravishankara, A. R.: Investigation of the loss processes for peroxyacetyl nitrate in the atmosphere - UV photolysis and reaction with $\mathrm{OH}$, J. Geophys. Res.-Atmos., 100, 14163-14173, doi:10.1029/95jd00545, 1995.

Teklemariam, T. A. and Sparks, J. P.: Gaseous fluxes of peroxyacetyl nitrate (PAN) into plant leaves, Plant Cell Environ., 27, 1149-1158, doi:10.1111/j.1365-3040.2004.01220.x, 2004.

Temple, P. J. and Taylor, O. C.: World-wide ambient measurements of peroxyacetyl nitrate (PAN) and implications for plant injury, Atmos. Environ., 17, 1583-1587, doi:10.1016/00046981(83)90311-6, 1983.
Turnipseed, A. A., Huey, L. G., Nemitz, E., Stickel, R., Higgs, J., Tanner, D. J., Slusher, D. L., Sparks, J. P., Flocke, F., and Guenther, A.: Eddy covariance fluxes of peroxyacetyl nitrates (PANs) and $\mathrm{NO}_{\mathrm{y}}$ to a coniferous forest, J. Geophys. Res.-Atmos., 111, D09304, doi:10.1029/2005jd006631, 2006.

Vilà-Guerau de Arellano, J., Patton, E. G., Karl, T., van den Dries, K., Barth, M. C., and Orlando, J. J.: The role of boundary layer dynamics on the diurnal evolution of isoprene and the hydroxyl radical over tropical forests, J. Geophys. Res.-Atmos., 116, D07304, doi:10.1029/2010jd014857, 2011.

Villalta, P. W., Lovejoy, E. R., and Hanson, D. R.: Reaction probability of peroxyacetyl radical on aqueous surfaces, Geophys. Res. Lett., 23, 1765-1768, doi:10.1029/96gl01286, 1996.

Wesely, M. L.: Parameterization of surface resistances to gaseous dry deposition in regional-scale numerical-models, Atmos. Environ., 23, 1293-1304, doi:10.1016/0004-6981(89)90153-4, 1989.

Wesely, M. L. and Hicks, B. B.: A review of the current status of knowledge on dry deposition, Atmos. Environ., 34, 2261-2282, doi:10.1016/s1352-2310(99)00467-7, 2000.

Wolfe, G. M., Thornton, J. A., Yatavelli, R. L. N., McKay, M., Goldstein, A. H., LaFranchi, B., Min, K.-E., and Cohen, R. C.: Eddy covariance fluxes of acyl peroxy nitrates (PAN, PPN and MPAN) above a Ponderosa pine forest, Atmos. Chem. Phys., 9, 615-634, doi:10.5194/acp-9-615-2009, 2009.

Zhang, J. M., Wang, T., Ding, A. J., Zhou, X. H., Xue, L. K., Poon, C. N., Wu, W. S., Gao, J., Zuo, H. C., Chen, J. M., Zhang, X. C., and Fan, S. J.: Continuous measurement of peroxyacetyl nitrate (PAN) in suburban and remote areas of western China, Atmos. Environ., 43, 228-237, doi:10.1016/j.atmosenv.2008.09.070, 2009.

Zhang, L., Moran, M. D., Makar, P. A., Brook, J. R., and Gong, S.: Modelling gaseous dry deposition in AURAMS: a unified regional air-quality modelling system, Atmos. Environ., 36, 537560, doi:10.1016/S1352-2310(01)00447-2, 2002. 